\title{
ANALYSIS OF EDUCATION MANAGEMENT POLICIES IN THE STANDARD FIELD OF FACILITIES AND INFRASTRUCTURE IN INDONESIAN ELEMENTARY SCHOOLS
}

\author{
Depi Elpina1i, \\ Marzam², \\ Rusdinal2, \\ Nurhizrah Gustituati ${ }^{2}$ \\ ${ }^{1 S M P N 2}$ Batang Gasan, \\ Pariaman, Indonesia \\ ${ }^{2}$ Universitas Negeri Padang, \\ Indonesia
}

\begin{abstract}
:
The purpose of this article is to know the management and policies based on the regulation of the Minister of National Education of the Republic of Indonesia No. 24 of 2007 relating to facilities and infrastructure for elementary schools. The method used is a literature study because it evaluates Indonesian education standards, particularly facilities and infrastructure in elementary schools. The results showed that the standard of facilities and infrastructure was still categorized as low because schools with complete facilities were only for schools with good accreditation; conversely, schools with good accreditation did not have complete facilities. The geographic area is the influence of each school. The geographic area of each school influences each school's geographic area for the standard of financing for facilities and infrastructure in elementary schools.
\end{abstract}

Keywords: management, policies, standards, education, facilities and infrastructure

\section{Introduction}

In the management and policy of Indonesian education, some standards are referred to develop and advance education. These standards include standards of content, process, assessment, competence, graduation, educators, educators and education personnel, facilities and infrastructure, financing, and management. This study focuses on facilities and infrastructure because this can be a determining factor in the success of the teaching and learning process. According to Zafar (2019), facilities and infrastructure are devices in the learning process smoothly and precisely (Barret et al., 2019).

${ }^{i}$ Correspondence: email depielpina1984@gmail.com, marzam1962@fbs.unp.ac.id 
In elementary schools, there are some facilities and infrastructure that determine the course of the teaching and learning process, such as classrooms, operator rooms, libraries, laboratories, and so on; another opinion states that infrastructure is a location, room, and building, while facilities include classrooms, books, And so on (Sutisna, 1985). Saidah (2019) reinforces this opinion that facilities and infrastructure a design for academics that runs smoothly with the facilities owned (Mirnda and Echeverry, 2010). By having completed facilities and infrastructure so that it makes students comfortable in the classroom. Another impact caused is that students easily accept learning from the teacher coupled with several methods and models in learning so students can quickly learn the lesson (Megasari, 2014; Okemwa and Momanyi, and Ntabo, 2020).

These facilities and infrastructure are indispensable in the teaching and learning process. It because they are included into regulated in the Law of the Republic of Indonesia No. 20 of 2003. this regulation concerns the national education system and consists of formal and non-formal education unit facilities and infrastructure. Facilities and infrastructure meet financial needs following the growth and development of physical potential, intellectual intelligence, emotional social, and the obligations of students.

If the facilities and infrastructure are inadequate, this can occur in low student learning outcomes (Ruhyana and Nur Aeni, 2019). Inadequate facilities, such as blackboards and damaged chairs, can interfere with the teaching and learning process in the classroom. If a country of facilities and infrastructure is damaged, then it can apply for the write-off of goods carried out annually in the use of state assets. The same is true if the facilities and infrastructure purchased can be included in the list of state assets (Adelman, et al., 2007).

\section{Literature Review}

This section describes relevant studies related to this research. The relevant study contains Indonesian education standards regarding facilities and infrastructure to support the teaching and learning process. The standard of facilities and infrastructure consists of fourteen sub-points that every elementary school must own, classrooms, library rooms, science laboratory rooms, leadership rooms, teacher's rooms, administration rooms, worship room, counseling room, UKS room, organization room. Student, latrine, warehouse, circulation room, and a place to play.

First, Firadusi (2020) examines policies and management of primary education related to standard policies for facilities and infrastructure in primary schools. This education policy and management are contained in the Minister of National Education of the Republic of Indonesia No. 24 of 2007. The results of research by Firdausi et al. (2020) show the form, purpose, and scope of facilities and infrastructure in elementary schools. This study provides a contents overview in regulation in Minister of National Education of the Republic of Indonesia No. 24 number 2007. 
Second, Tanjung, Annisa, and Ridwan (2016) discussed the analysis of primary school facilities and infrastructure based on accreditation in Tarakan City. The research results by Tanjung, Annisa, and Ridwan (2016) state that schools that have good accreditation have adequate facilities and infrastructure. As evidenced, it is found that $80.9 \%$ and good enough schools also show the facilities and infrastructure. Unfavorable, with a gain of $55.3 \%$. The results of their research explained that the higher the accreditation a school has, the more complete the facilities and infrastructure owned by the school (Pohan, 2018).

Third, Armalena (2020) describes facilities and infrastructure at Muhammadiyah Elementary Schools in Padang City. Armalena et al. (2020) stated that the results were good because they used a Likert scale model questionnaire to class teachers and elementary school employees with $72.42 \%$. The results of this acquisition are not relevant to the results of research in the field because the questionnaire results are inversely proportional to the results of research in the field after All teachers and school employees are not honest in filling out the questionnaire.

Fourth, Munir (2014) discusses the analysis of the availability of basic education facilities and infrastructure in the Gubug District, Grobongan Regency. Munir's research (2014) shows that it does not affect the availability of basic education facilities and infrastructure. The results of Munir's research concluded that the availability of facilities and infrastructure is insufficient because it is caused by topographic factors and the population of primary education age (Elmunsyah, 2012; Mujahid and Noman, 2015).

Fifth, Megasari (2015) describes improving educational facilities and infrastructure to improve the quality of learning at SMP 5 Bukitinggi. The results showed that there were management, procurement, utilization maintenance that were already running. These four factors are indicators of the effectiveness of the teaching and learning process. The results of this study are helpful in improving the quality of learning and creating conducive learning conditions.

Sixth, Pratiwi and Annisa (2017) explain the analysis of the implementation of primary school education management based on national education standards in coastal areas. The research objective of Pratiwi and Annisa (2017) is to describe and analyze the suitability of primary school education management based on national education standards in the coastal area of Tarakan. The results of this study indicate the suitability between management and planning by achieving results as much as $92.6 \%$. The results of this acquisition have not been seen in the aspects of fulfilling the quality of services and students because the leadership and management of management information systems are not yet optimal.

\section{Material and Methods}

The method used in this paper is a literature study because it describes the regulation of the Minister of National Education of the Republic of Indonesia No. 24 of 2007 with the facilities and infrastructure for elementary schools of Indonesia. The literature study 
discussed in this research on Indonesian education standards is in the Minister of National Education of the Republic of Indonesia No. 4 of 2007 in the form of a collection of various reading sources, such as books, journals, articles, and reading materials that are the sources of this research.

\section{Results and Discussion}

Following are the results of several literature studies related to educational standards regarding facilities and infrastructure by explaining the 14 sub-points in ministerial regulation No. 24 of 2007, namely classrooms, library rooms, science laboratory rooms, leadership rooms, teacher's rooms, administration rooms, places of worship, counseling rooms, UKS rooms, student organization rooms, latrines, warehouses, circulation rooms, and a playground/exercise body.

All of the above sub-points of educational facilities and infrastructure standards are also regulated in the Republic of Indonesia Government Regulation No. 19 of 2005 concerning National Education standards chapter VII article 42 paragraph 1 and 2:

a) Each academic unit is obliged to have facilities including furniture, educational equipment, books, and other learning resources, consumables, and equipment needed to support an orderly and continuous learning process.

b) Each academic unit includes land, classrooms, leadership rooms, teacher's rooms, library rooms, laboratory rooms, canteens, sports and worship places, playgrounds, recreation areas, and other spaces needed to support the learning process. Regular and ongoing.

Between Ministerial Regulation No. 24 of 2007 and Government Regulation No. 19 of 2005, there is conformity with national education standards regarding facilities and infrastructure (Nurhayati, 2021). For this reason, based on the fourteen sub-points in this study, it can be divided into four subsections, namely form, definition, purpose, and scope of facilities and infrastructure. The following is an explanation of the four points. Standard Definition of Facilities and Infrastructure

Facilities and infrastructure are needed to support the teaching and learning process. Facilities and infrastructure can be interpreted as equipment to achieve management standards and educational policies. Facilities and infrastructure need to be developed in order to interpret the learning process itself. The process of developing facilities and infrastructure in schools requires management. It is necessary for planning, procurement, regulation, use, and deletion (Indrawan, 2015; Kurniawan, Sukristyanto, and Tjahjono, 2020).

All equipment used in learning, whether it can be used or not, is called means, while additional equipment, namely supporting equipment. There are two types of infrastructure, the academic unit building consisting of a material place, an administration place, a library place, and an environment. Educational unit equipment is a building for classrooms (Ellong, 2007). As for infrastructure, it is the location of the room and building. Meanwhile, the facilities are classrooms, books, and others (Sutisna, 
1985). Based on some of the definitions above, it can be concluded that facilities and infrastructure is designed for academics so that the teaching and learning process runs smoothly (Saidah, 2019). With complete and adequate facilities and infrastructure, schools can progress and develop rapidly. Student's skills are strongly influenced by the complete facilities and infrastructure in units. Good education should be equipped with complete instructors and infrastructure, both private and public (Kartika, 2019; Beaton, 1999).

\subsection{Facilities and Infrastructure Form}

According to Novita (2017), the form of facilities and Infrastructure is divided into 3 parts, along with an explanation.

1. Tools that run out slowly and quickly run out when used. These tools are categorized into three parts

a. Tools that wear out quickly, such as chalk, markers, and chemicals. Tools that change quickly, for example wood, iron, and cardboard. The tools needed in learning are laptops, lamps, and books.

b. Tools that are slow to run out, such as chairs, tables, maps, and some equipment in the field.

2. The tools used are based on the motion, for example

a. Movable devices, such as cabinets, chairs, and tables.

b. Tools that cannot move, such as electricity and water.

3. Facilities in the teaching and learning process, such as learning tools, teaching aids, and teaching facilities.

a. Learning tools that are immediately used, such as writing tools, and practice

b. Teaching aids are learning aids, such as real and unreal perceptions

c. Teaching media that support the learning process. There are 3 forms of facilities, namely sound facilities, image facilities, and sound and image facilities.

There are two types of infrastructure in schools, for example (1) infrastructure used for the implementation of learning, such as a theory place, a librarian place, skills practice place, and a laboratory area. (2) infrastructure used to support learning activities, such as the headteacher room, land access and roads to schools, restrooms, school health business rooms, teacher's rooms, the head teacher room, and the sports hall (Novita, 2017)

The function of the room/place is (a) a place of education; (b) place of administration; (c) supporting place; (d) places for educational tools and media; bookkeeping or teaching materials; (f) educational facilities and infrastructure (Kartika, 2019).

Based on the explanation above, it can be said that there are forms of facilities and infrastructure, namely writing instruments, places, buildings, places to read books, places to study, places for meetings, places for administration, labour, canteens, and 
others. If all the facilities and infrastructure are adequate, it can increase student and community interest in schools because the quality and quality of the school is based on adequate facilities.

\subsection{Purpose of facilities and infrastructure}

According with Parid (2020), there are (1) preparation of facilities and props based on their preparation and provision, (2) striving for the effectiveness of the implementation of school facilities and equipment; (3) assisting in the operation of the implementation of facilities; (4) endeavor to conserve facilities and tools so that they can be used when needed. Another opinion states the function of facilities and infrastructure, namely to fix the room, place, and everything that is moving or not so that the learning objectives are achieved and the learning situation in the classroom is comfortable (Wilkinson, 2002; Herpratama dan Sunimaryanti, 2019)

From the understanding of the purpose of facilities and Infrastructure above, it can be concluded that the purpose of facilities and Infrastructure is to increase the interest of the community students to study comfortably in a classroom equipped with adequate facilities. In addition, it can strengthen student's memory, skills, and their memorization is influenced by complete facilities and infrastructure. Thus, schools must provide adequate facilities to attract the interest of the community and students in the learning and teaching process.

\subsection{Scope of facilities and infrastructure}

According to Parid (2020), there are five groups in the scope of facilities and infrastructure, namely

1. Design: in the design there is a budget for school needs

2. Provision: provision of facilities and Infrastructure can be done by all parties involved in the school

3. Inventory: the activity of recording or registering school-owned goods into an orderly and orderly list of goods inventories according to the applicable provisions and procedures.

4. Preservation: through preservation can maintain facilities with care carried out by all school members so that they are not damaged, do not shrink, are neat, and periodically (Saidah, 2019)

5. Omission: the meant disappearance is a facility that cannot be used, is heavily damaged, and is out of date.

There are several conditions in place to maintain the facility so that it can be used in the future

a) Standard representation of form, quality, and capacity;

b) Increase the required equipment;

c) Prepare and use operational tools;

d) Follow facilities and Infrastructure management procedures;

e) Planning items that can be used; 
f) Planning for items that are slow and used up;

g) Planning goods that run out of use;

h) Planning goods that are not running out of use;

i) Calculating learning facilities.

Maintenance of goods is needed from time to time so that goods are not easily damaged, neat, and clean (Nasruddin, 2018). In addition, teachers have a very important role in facilities and Infrastructure in order to maintain and supervise these infrastructures.

\section{Conclusion}

The study results indicate that primary school facilities and infrastructure in Indonesia have not been well managed because they are influenced by school accreditation and varied regional topographies so that a review of education management and policies is required in the standard content of facilities and infrastructure in ministerial regulations.

\section{Conflict of Interest Statement}

The authors declare no conflicts of interests.

\section{About the Authors}

First author, Depi Elpina, works as teacher at SMPN 2 Batanng Gasah, Pariaman. Her research interest is math. The second author, Marzam, works at Universitas Negeri Padang; his research interest are art, drama, dance, and music. The third and fourth authors are Rusdinal and Nurhizrah; they work at Universitas Negeri Padang. Their research interest is education.

\section{References}

Adelman, et al. (2007). Toward a School District Infrastructure That More Effectively Addresses Barriers to Learning a Teaching: A Center Policy and Practice Analysis Brief, Los Angles: Center for Mental Health in School at UCLA.

Armalena (2020). Pengelolaan Sarana dan Prasarana di Sekolah Dasar Muhammadiyah Kota Padang, Jurnal Penelitian Ipteks, 5 (1), 89-100.

Barret, et al. (2019). The Impact of School Infrastructure on Learning, International Bank for Reconstruction and Development. Washington DC: Tigran Shims.

Beaton Ken (1999). Modernising the School Infrastructure in England, International Symposium, 1-12.

Ellong, T. D. A. (2007). Manajemen Sarana Dan Prasarana Di Lembaga Pendidikan Islam. Pendidikan Islam Iqra', 11(1), 1-8.

Elmunsyah Hakkan (2012). A Study of ICT Infrastructure and Access to educational Information in the Outskirt of Malang, Acta Didactica Napocensia, 5 (2), 41-49. 
Flardo Mary (2017). Adequate and Equitable U.S Pk 12. USA: National Council on School Facilities, and Center for Green Schools.

Herpratama Ellan and Sumaryanti (2019). Creativity of Physical Education Teacher in Modifying Leaning Facilities and Infrastructure, International e-Journal of Educational Studies, 3 (6), 157-166.

Indrawan, I. (2015). Pengantar Manajemen Sarana dan Prasarana Sekolah. Deepublish.

Kartika, S. (2019). Pengaruh Kualitas Sarana dan Prasarana terhadap Minat Belajar Siswa dalam Pembelajaran Pendidikan Agama Islam. 7(1).

Kurniawan Satunggale, Sukristyanto Agus, Tjahjono (2020). Evaluation of Public Policy of National Standard Education on Elementary School in Porong Sub-district Sidoarjo District, Journal of Public Policy and Administration, 4 (3)m 42-50.

Megasari, R. (2014). Peningkatan Pengelolaan Sarana dan Prasarana Pendidikan Untuk Meningkatkan Kualitas Pembelajaran Di SMPN 5 Bukittinggi. Jurnal Administrasi Pendidikan, 2(1), 636-831.

Miranda Norbella and Echeverry Patricia Angela (2010). Infrastructure and Resources of Private Schools in Cali and The Implementation of The Bilingual Colombia Program, A Colombian Journal for Teachers of English, HOW-17, 11-30.

Mujahid Nooreen and Noman Muhammad (2015). Infrastructure Availability in The Public Sector Schools: A Case Study of Sindh Province, Journal of Education and Practice, 6 (4), 60-67.

Munir (2014). Analisis Ketersediaan Sarana dan Prasarana Pendidikan Dasar di Kecamatan Gubug Kabupaten Grobongan. Thesis. Universitas Muhammadiyah Surakarta.

Nasruddin (2018). Manajemen Sarana dan Prasarana Pendidikan Dalam Proses Pembelajaran Di SD Negeri Ngrukeman Tamantirto Kaihan Bantul.

Novita, M. (2017). Sarana Dan Prasarana Yang Baik Menjadi Bagian Ujung Tombak Keberhasilan Lembaga Pendidikan Islam. NUR ELISLAM : Jurnal Pendidikan Dan Sosial Keagamaan, Volume 4,(2), 127.

Nurhayati Lia (2021). Policy Effectiveness Program for Improving Education Equality through The Development Education Facilities and Infrastructure, Journal of Education Review Provision, 1 (1), 6-11.

Okemwa Ondara Kennedy, Momanyi Marcella, and Ntabo Anyona (2020). Influence of Board of Managements' Infrastructure Development Practices on Students' Academic Performance in Public Secondary Schools in Nymira Country Kenya, African International Research Journal, 8 (3), 575-585.

Parid, M. \& A. L. S. A. (2020). Pengelolaan Sarana dan Prasarana Pendidikan. Jurnal Tafhim Al-Ilmi, 11(2), 266-275.

Pohan Rahmadanni (2018). Management of Basic School Management and Infrastructure in Pasir Penyu District, Indonesian Journal of Education and Learning, 2 (1), 174185.

Rahmawati, M. (2019). Pengertian Administrasi Sarana dan Prasarana. 1-3. 
Ruhyana Fitria Nugraha and Nur Aeni Ani (2019). Effect of Educational Facilities and Infrastructure in Primary School on Students' Learning Outcomes, Mimbar Sekolah Dasar, 6 (1), 43-63.

Saidah, N. (2019). Pengertian, Proses Administrasi Sarana dan Prasarana.

Setyaningih, S. (2018). Pengelolaan sarana prasarana dalam implementasi kurikulum pendidikan guru sekolah dasar: Sebuah studi kasus di Universitas Negeri Semarang. Jurnal Managemen Pendidikan, 13(1), 62-71.

Sutisna, O. (1985). Administrasi Pendidikan: Dasar Teoritis untuk Praktek Profesional. Angkasa.

Tanjung Zona Firima, Aniisa Muhsina, and Ridwan (2016). Analisis Sarana dan Prasarana Sekolah Dasar berdasarkan Tingkat Akredditasi di Kota Tarakan, Jurnal Pendidikan Indonesia, 5 (2), 134-146.

Wilkinson Richard (2002). Monitoring and Evaluation of Public Policies for Educational Infrastructure, The International Seminar on Educational Infrastructure, 1-9.

Zafar, M. A. \& H. A. (2019). Administrasi Sarana dan Prasarana. Jurnal Administrasi Sarana Dan Prasarana, 1, 4. 
Creative Commons licensing terms

Author(s) will retain the copyright of their published articles agreeing that a Creative Commons Attribution 4.0 International License (CC BY 4.0) terms will be applied to their work. Under the terms of this license, no permission is required from the author(s) or publisher for members of the community to copy, distribute, transmit or adapt the article content, providing a proper, prominent and unambiguous attribution to the authors in a manner that makes clear that the materials are being reused under permission of a Creative Commons License. Views, opinions and conclusions expressed in this research article are views, opinions and conclusions of the author(s). Open Access Publishing Group and European Journal of Education Studies shall not be responsible or answerable for any loss, damage or liability caused in relation to/arising out of conflicts of interest, copyright violations and inappropriate or inaccurate use of any kind content related or integrated into the research work. All the published works are meeting the Open Access Publishing requirements and can be freely accessed, shared, modified, distributed and used in educational, commercial and non-commercial purposes under a Creative Commons Attribution 4.0 International License (CC BY 4.0). 